\title{
EDITORIAL: GLOBALISATION WILL ONLY MEAN PROGRESS IF IT IS RESPONSIBLE
}

'The world is my country'. Those famous words by Thomas Paine express the idea of a common thread linking all humankind and transcending distances, borders, and nations. The industrial revolution first, and then globalisation, gave that idea new impetus. Today, we are more connected than we have ever been - because of our travels, our means of communication, and our business exchanges. The private sector has largely contributed to this development: the business activities of our national and multinational companies have woven a complex web of mutual interdependencies.

Globalisation is for the better when we derive mutual benefit from our respective advantages but for the worse when what takes place is not an exchange but exploitation. The ambivalence of this phenomenon is sensed the most acutely in those parts of the world that are plagued by conflict and violence: economic factors are often either the direct causes of violence, or are at least likely to inflame and perpetuate violence.

Like the thirst for wealth that drove the conquerors of the New World, countless wars have been driven or prolonged by dynamics associated with acquiring property or resources, gaining control over new markets, and economic expansion. For several decades, Africa has witnessed its share of conflicts being fuelled, among other things, by the existence of resources sought by the opposing parties - one could mention Sierra Leone, Liberia, the Democratic Republic of the Congo and its neighbours, Nigeria, and so on. Central and South America have also had their fair share of conflict or social turmoil linked to the desire to gain access to resources or control of export routes - Colombia, Peru and Mexico come to mind, for example. Turning to Asia, and Afghanistan in particular, the current fear is that the recent awareness of its vast mining potential will cause Afghanistan to experience a deterioration in rivalries, violence, and corruption at the expense of a peaceful transition after the withdrawal of international forces. ${ }^{1}$ Afghanistan would thus become a new illustration of what is sometimes called 'the resource curse', or the paradox by which countries rich in resources tend to be less developed and to experience less rapid growth than countries that have none. ${ }^{2}$

While economic stakes have nurtured conflict throughout history, the imprint of multinational business enterprises on international relations and security matters has never been greater. Thus, in some areas plagued by armed conflict or violence, public authorities can barely exercise any control, whereas business actors have acquired more and more influence and have assumed some functions 
traditionally incumbent on the state. It is therefore not uncommon to see private enterprises being directly responsible for the security of a geographical area or equipping and providing supplementary training for public security forces - with minimal involvement by the state or even a total absence of state structures.

What are the main facets of the relationship between business actors and conflict today? What rules exist to regulate their activities? This issue of the Review does not address all the relations between war and the economy, such as arms trade, black market economies and trafficking, or the economic aspects of humanitarian aid. Instead, the Review has decided to highlight the rights and responsibilities of companies working in areas of armed conflict and other situations of violence. Having devoted a previous issue to the subject of international regulation of private military and security companies, the journal now looks at the latest developments in the interaction between business and conflict. ${ }^{3}$

Whether they have already been established in a country before a conflict or whether they are investing in a region already in crisis, business enterprises will influence the course of the conflict by virtue of their actions, their influence, or their mere presence. As Hugo Slim explains in his article, business actors play a number of different roles. Only some of them are covered here. ${ }^{4}$

First of all, business actors often find themselves the victims of acts of violence, as illustrated by the recent attack on and hijacking of the oil plant in Amenas, Algeria. They expose themselves to direct risks such as the exertion of pressure, extortion, pillage, hostage-taking, and attacks.

Second, business actors may contribute to the violence-directly or indirectly, voluntarily or involuntarily. They may represent a source of income for the conflict parties or even provide them with the means of fighting. In the most extreme cases, they may take advantage of war, chaos, and violence to engage in criminal activities, like the German enterprises that contributed directly to the implementation of Nazi policies and/or exploited the slave labour in the Nazi camps during the Second World War.

Finally, business actors can play a positive role by contributing to relief and the prevention or reduction of violence. Investors who, despite the risks, keep their business operations going in conflict areas enable their employees to maintain an income and may help to ensure a degree of stability. History also provides numerous examples of direct humanitarian action by business companies and their managers. Henry Dunant, who was at the origin of the foundation of the International Red Cross and Red Crescent Movement, was himself a businessman who happened

1 See Graham Bowley, 'Potential for a mining boom splits factions in Afghanistan', in The New York Times, 8 September 2012, available at: www.nytimes.com/2012/09/09/world/asia/afghans-wary-as-efforts-pickup-to-tap-mineral-riches.html?_r=3\& (all internet references were accessed in December 2012).

2 A study of developing countries conducted by Jeffrey Sachs and Andrew Warner in 1995 revealed that the more an economy is dependent on mineral resources, the weaker its growth rate. See Jeffrey D. Sachs and Andrew M. Warner, 'Natural resource abundance and economic growth', in NBER Working Paper Series, Working Paper 5398, Harvard Institute for International Development, 1995.

3 See the edition on the subject of 'Private military companies', International Review of the Red Cross, Vol. 88, No. 863, September 2006.

4 See the article by Hugo Slim in this issue. 
across the horrors of war while on a business trip. The film industry has popularised what the German entrepreneur Oskar Schindler did to help his Jewish employees who were persecuted during the Second World War (Schindler's List), and the action taken by Paul Rusesabagina, who used his influence as a hotel manager to protect hundreds of people's lives during the genocide in Rwanda (Hotel Rwanda).

Recently, the government and the private sector jointly financed the occupational reintegration of combatants who had formerly taken part in the conflict in Côte d'Ivoire, providing another example of a way in which private enterprises can help. ${ }^{5}$ Lastly, private enterprises are also major donors of humanitarian aid.

\section{Social responsibility and legal responsibility: the increasing regulation of economic activities}

Unlike those of states, armed groups, and individuals, the rights and obligations of private companies and their agents during armed conflict have long remained vague and the applicable standards piecemeal and fragmented. Today, various legal and social sources and several confluent movements are helping to make the private sector more aware of its responsibilities.

\section{Binding obligations under international law}

Before describing the ever growing web of voluntary initiatives seeking to regulate business behaviour that can impact on human rights, it may be useful to recall that there is already a set of binding rules relevant to business behaviour in volatile contexts.

In international human rights law, states have the primary role in preventing and addressing corporate-related human rights abuses. To fulfil their duty to protect, states must be able to regulate and adjudicate on the behaviour of the actors involved in abuses. Such actors include business enterprises. ${ }^{6}$

In times of armed conflict, international humanitarian law (IHL) is the prevailing legal regime. It contains provisions that protect civilians and civilian property, which includes staff and property of companies operating in an armed conflict. It also imposes obligations on states, individuals, and non-state parties to the conflict.

IHL makes it incumbent on states (be they home states, territorial states, or contracting states) to 'respect and to ensure respect for' IHL, ${ }^{7}$ including by adopting appropriate domestic legislation where necessary. States are explicitly obliged to

5 See 'In Côte d'Ivoire the government and private companies are partnering to create jobs for young men and women', in worldbank.org, 27 August 2012, available at: www.worldbank.org/en/news/feature/2012/ 08/27/in-cote-d-ivoire-the-government-and-private-companies-are-partnering-to-create-jobs-for-youngmen-and-women.

6 For a detailed study of states' duty to protect, see the article by Rachel Davis in this issue.

7 See Art. 1 common to the four Geneva Conventions of 1949. 
criminalise grave breaches of IHL in their national legislation, as well as to investigate and prosecute such offences. ${ }^{8}$ Hence individuals, including executives or employees of business enterprises, may be held individually criminally responsible for violations of IHL.

International criminal law too has evolved significantly since the Second World War, and today executives or staff of corporate entities may be held accountable not just for violations of IHL but also for other international crimes under an ever more sophisticated web of modes of liability. In parallel, many national jurisdictions have increasingly adopted legislation that allows them to address transnational and international crimes through criminal or civil liability. ${ }^{9}$ Civil liability for corporations, in particular, has been one avenue of accountability that has been explored in the past decade. ${ }^{10}$ Knowledge of the relevant rules of national law, as well as of international human rights law, IHL, and international criminal law, is therefore crucial for local and international business enterprises operating in volatile contexts.

\section{Development of soft-law instruments}

Since the 1990s and the growing awareness of the social and environmental imprint of business enterprises in volatile contexts throughout the world, there has been a marked increase in efforts to regulate business conduct - regardless of whether this takes place under the aegis of the United Nations (UN), industry associations, or multi-stakeholder initiatives. ${ }^{11}$ Those efforts have generally focused on developing soft-law standards and self-regulation.

There are different ways to explain this push. Sceptics suggest that such soft-law approaches simply conceal the inability of states to govern companies and serve the companies' own public relations interests. Others suggest that soft-law instruments are a more effective means of norm creation because they avoid doctrinal debates about whether business enterprises are actually subjects of international law and because the formal procedures for drawing up treaties take too long to be able to regulate the quickly evolving private sector. Others still point to a genuine search for new forms of global governance, based on a voluntary and

8 See the provisions of the Geneva Conventions relating to grave breaches, Arts. 50, 51, 130, 147 of the First to Fourth Geneva Conventions respectively, and Arts. 11 and 85 of Additional Protocol I to the Geneva Conventions.

9 See the example of Norway, presented in the article by Simon Mark O'Connor in this issue.

10 With regard to civil litigation in particular, see the Alien Tort Claims Act in the United States, which has enabled civil proceedings to be instigated for violations of IHL by business enterprises.

11 At the intergovernmental level, they include the International Labour Organisation's Tripartite Declaration of Principles concerning Multinational Enterprises and Social Policy, the Organisation for Economic Cooperation and Development's Guidelines for Multinational Enterprises, and the Performance Standards for companies established by the International Finance Corporation. Among the multi-stakeholder initiatives, reference can be made to the UN Global Compact, the Voluntary Principles on Security and Human Rights, the Extractive Industries Transparency Initiative, and the Kimberley Process certification scheme. The Voluntary Principles, in particular, are an example of a multi-stakeholder initiative on companies and human rights that refers specifically to international humanitarian law. 
inclusive approach to tackling global problems. Those in favour of such initiatives also say that multi-stakeholder approaches, in particular, tend to blur the distinction between what is voluntary and what is mandatory to such an extent that they could contribute to crystallising future hard law. Whatever approach is adopted, it is now a given that a set of soft-law instruments will develop. However expansive it might be, that set of instruments is increasingly unclear and often specific to a particular forum or industry.

In 2008, in a push towards a holistic legal framework for regulating business behaviour which may have an impact on human rights, the UN established a general framework on business and human rights, addressing the three main stakeholders: governments, business, and civil society. Developed by John G. Ruggie, Special Representative of the UN Secretary-General on the issue of human rights, and transnational corporations and other business enterprises, the Protect, Respect and Remedy Framework is based on extensive consultations with those three sectors. The document introduces a new approach to regulation at the international level: it reminds states of legal obligations, business enterprises of their responsibility and interest in managing the risks of human rights violations, and civil society of its responsibility to understand and use available remedies in case of violations.

The Protect, Respect and Remedy Framework was followed by the adoption of the Guiding Principles on Business and Human Rights, unanimously adopted by the UN Human Rights Council, which aim at operationalising the Framework. Today, the Guiding Principles represent a key reference document in the field of business and human rights. They contain practical recommendations for each of the stakeholders. The next stage will consist of the stakeholders integrating and internalising those Principles. Some progress can already be observed, as Rachel Davis notes in her article. ${ }^{12}$

\section{The regulation of private military and security companies}

One particular type of business enterprise which is, by definition, more exposed to armed conflict and other situations of violence is private military and security companies (PMSCs). Following the recent era in which mercenaries hired out their services as soldiers of fortune in the African conflicts, the wars in the Balkans, in Iraq, and in Afghanistan have seen the emergence of new structures providing military and security-type services: PMSCs. In the face of growing demand, there has been an increase in the number of PMSCs, which have extended their range of services to include security, logistics, maintaining and operating military equipment, intelligence, training of police and armed forces, and detention-related activities, to name a few. In fact, one can speak of a veritable private military and security industry that is providing an ever broader range of services, increasingly today in the field of maritime security in response to piracy (delivery of ransom money, negotiations, sea patrols, and so on). This multifaceted and quickly evolving nature 
of the services provided by PMSCs poses significant challenges to developing a coherent legal framework governing their activities.

In terms of the existing legal obligations, the 2008 Montreux Document, ${ }^{13}$ spearheaded by Switzerland and the International Committee of the Red Cross (ICRC), restates and reaffirms the law applicable to the activities of PMSCs in armed conflicts, and recommends a catalogue of good practices for the practical implementation of these existing legal obligations. The document focuses on states' obligations, including the obligations of states that contract PMSC services, of those under whose jurisdiction the PMSCs are incorporated or registered, and of those on whose territory PMSCs operate.

At the UN, efforts focus primarily on monitoring the impact of private military and security providers on human rights and on considering the possibility of elaborating an international convention to regulate the activities of private military and security companies. ${ }^{14}$

There is also a recent tendency towards self-regulation within the industry. The most recent initiative of this kind, which is also an example of a multistakeholder process, is the International Code of Conduct for Private Security Service Providers (ICoC). ${ }^{15}$ Facilitated by the Swiss government and the Centre for the Democratic Control of Armed Forces (DCAF) foundation, this initiative sets out a code to guide private security service providers on how to operate in accordance with IHL and international human rights standards (in particular on questions related to the use of force, detention, sexual exploitation and abuse, human trafficking, and slavery). The ICoC refers to the Montreux Document and importantly provides an oversight mechanism - a unique characteristic of this instrument. It remains to be seen how the mechanism will work in the future. In the meantime, it is important to recall that self-regulation is no substitute for the responsibility of states to ensure respect for IHL by PMSCs during armed conflict and that the staff and management of PMSCs remain bound by the rules of IHL when they operate in armed conflict.

\section{Business as usual or a change in global governance?}

In light of all these developments, one could say that some progress has been made at the international level in terms of the dialogue between civil society, business, and

13 More than 45 states and the European Union have now signed the Montreux Document.

14 See the mandate of the Working Group on the use of mercenaries as a means of violating human rights and impeding the exercise of the right of peoples to self-determination in Resolution 2005/2 of the UN Commission on Human Rights (UN Doc. E/CN.4/RES/2005/2, 7 April 2005), extended by Resolution 7/21 of the UN Human Rights Council (UN Doc. A/HRC/RES/7/21, 28 April 2008). See also Resolution $15 / 26$ of the UN Human Rights Council, which provides for the establishment of an open-ended intergovernmental working group to explore the possibility of drafting an international convention to regulate, control, and supervise the activities of private military and security companies (UN Doc. A/HRC/RES/15/26, 7 October 2010).

15 The description of the ICoC is available on the website of the Centre for the Democratic Control of Armed Forces. See 'International Code of Conduct for Private Security Service Providers', available at: www.dcaf. $\mathrm{ch} /$ Project/International-Code-of-Conduct-for-Private-Security-Service-Providers. 
states on the question of the responsibilities of business actors under IHL and human rights law. There is, however, still a long way to go. Although the Guiding Principles were unanimously adopted by the UN Human Rights Council and thus benefit from an unprecedented legitimacy at the international level, many business enterprises are not yet aware of their existence. They are even less knowledgeable about the ways of implementing the Principles in their operations.

In addition, the fact that several of today's soft-law initiatives tend to focus on corporate conduct should not obfuscate states' own responsibilities under international law. Governments today are thus increasingly expected to think actively about what concrete steps they can take in order to prevent and mitigate corporate-related human rights abuses.

Looking ahead, there may be a need to reflect more carefully on available remedies for those bearing the brunt of IHL and human rights violations. What sorts of grievance mechanisms should and could be put in place for sanctioning or repairing the damage caused to vulnerable communities as a result of business operations? Can non-judicial grievance mechanisms work to effectively address community concerns in the future? Or is there a risk that such mechanisms may be unevenly applied, not sufficiently independent, or unable to lead to effective sanctioning? Ought the push in the future be towards more non-judicial remedies, or rather towards better state regulation and access to justice through national courts? These remain open questions, but it seems that initiatives aiming at ensuring better respect for human rights by the private sector can only be given practical meaning if they also include effective accountability mechanisms and recourse for victims.

\section{The role of civil society}

International civil society will also have a role to play in monitoring the activity of the private sector, making company directors aware of their responsibilities, and providing advice for affected communities or for victims of abuse. Thus, for example, the non-governmental organisation (NGO) Business \& Human Rights Resource Centre has a Corporate Legal Accountability Portal, an 'online information hub providing resources for non-lawyers as well as lawyers - including victims, advocates, NGOs, businesspeople, lawyers bringing lawsuits against companies and lawyers defending companies'. ${ }^{16}$ The Institute for Human Rights and Business (IHRB) also strives to be a 'centre of excellence and expertise on the relationship between business and internationally proclaimed human rights standards'. ${ }^{17}$ More recently, Shift, an independent non-profit centre for business and human rights, was established by experts who had taken part in drawing up the Guiding Principles on Business and Human Rights with a view to providing

16 The Corporate Legal Accountability Portal is available at: www.business-humanrights.org/LegalPortal/ Home/ProjectDescription.

17 The IHRB's website is available at: www.ihrb.org. 
practical assistance for governments, business enterprises, and their partners on implementing the Principles. ${ }^{18}$ Nowadays, local NGOs, countries, and regions directly affected are at the origin of initiatives to implement the Guiding Principles. Hence, at the international level, the move towards full implementation of a framework such as the Guiding Principles will require alignment within the global standard-setting bodies (the UN, intergovernmental and regional organisations) and an effort to strengthen the capacity targeting the three aforementioned groups of stakeholders: governments, business enterprises, and civil society.

\section{Business enterprises and humanitarian agencies: an indispensable dialogue}

Business enterprises today have a greater awareness of their social responsibilities. It may be that they feel under pressure from their clients, who increasingly think like citizens of a more interdependent world; it might also be that they are keenly aware of the interests of their own shareholders and of the purely reputational costs of any alleged wrongdoing. The globalisation of communication via the media or social networks is also lending greater depth to Dostoyevsky's affirmation: 'Everyone is responsible to everyone for everything.'

Nevertheless, while the economy has always been one of the core concerns of development actors, humanitarian organisations have only relatively recently taken account of the role of business actors, often with little support. The development of self-regulation initiatives in the private sector and the awareness by humanitarian agencies of its growing influence calls for an intensification of contacts and cooperation. ${ }^{19}$ Humanitarian and business actors operating in a crisis area have all the more reason to communicate with each other as they often share the same interlocutors, such as armed and security forces, armed groups, criminal gangs, and threatened communities.

While business enterprises are geared to profit and are not called to carry out humanitarian action, it is on the basis of complementarities between the two sectors that cooperation mechanisms should be sought. The private sector will be able to step in where humanitarian agencies indicate there is need, which the latter are better placed to identify and assess. Several areas of dialogue could be explored: one could think of joint analyses of the effects on communities of the activities of business enterprises, the exchange of non-confidential information on economic or security risks, the transfer of skills or logistics and communication means, and so on.

The examples of the new media and telecommunications industries provide an illustration of the humanitarian contribution that may be made by the private

18 The Shift website is available at: www.shiftproject.org.

19 See, for example, 'Commercial and humanitarian engagement in crisis contexts: current trends, future drivers', in Humanitarian Futures Programme, King's College, London, July 2011, available at: www. humanitarianfutures.org/publications/commercial-and-humanitarian-engagement-in-crisis-contextscurrent-trends-future-drivers/. 
sector in case of crisis and of the value of strengthening cooperation. For instance, during the violence in southern Kyrgyzstan in June 2010, the ICRC had to deal with problems of gaining access to the conflict areas and turned to the national telecommunication companies, which sent, free of charge, text messages to all their subscribers, appealing for respect for the humanitarian mission.

While close cooperation of this kind may exist in crises, it would evidently be desirable to set up advance coordination and preparation mechanisms. In the 150 years of its history, the ICRC has maintained relatively few relations with the private sector. It was not until recently that the organisation developed a strategy for involving the private sector in a bid to strengthen its capacity to provide assistance and protection for conflict victims. ${ }^{20}$

The starting point for that strategy is the principle that business may be a force for good - including in situations of armed conflict or in violent contexts provided that business enterprises demonstrate the greatest diligence in the conduct of their activities. The primary objective of that strategy is thus to help business enterprises to know their rights and to fulfil their obligations under IHL. To that end, the ICRC is endeavouring to establish relations and to conduct a dialogue with companies likely to have a direct or indirect influence on the fate of victims of armed conflict or situations of violence.

As part of initiatives in the area of corporate social responsibility, companies have approached the ICRC to offer their support for its humanitarian activities. The ICRC has also contacted several business enterprises in order to strengthen its capacities for action in the field as a result of exchanges of expertise. In 2005, the ICRC and a group of business companies established the Corporate Support Group, ${ }^{21}$ which brings together enterprises that have decided to support the ICRC's humanitarian mission. The ICRC has also equipped itself with guidelines to determine the framework of its partnerships with the private sector. ${ }^{22}$

This issue of the Review sets out to be practical and useful first and foremost for members of the private sector who may be seeking to improve their understanding of armed conflict or other situations of violence and to fulfil their obligations in such situations. The Review would also like to contribute to reinforcing the understanding of the role and obligations of the private sector among humanitarian agencies in the field and political decision-makers in charge of developing the applicable law.

20 See the article by Claude Voillat in this issue. See also the page 'Relations between the ICRC and the private sector' on the ICRC website, available at: www.icrc.org/eng/what-we-do/other-activities/privatesector/overview-private-sector-relations.htm.

21 See 'The ICRC Corporate Support Group - a mutually beneficial partnership', 18 January 2010, available at: www.icrc.org/eng/resources/documents/misc/private-sector-271008.htm.

22 See 'Ethical principles guiding the ICRC's partnerships with the private sector', available at: www.icrc.org/ eng/resources/documents/misc/ethical-principles-220502.htm. 
The views assembled in this issue come from researchers and practitioners from different fields: academics, specialist private sector business advisers, and members of international NGOs and UN agencies. The Review also wished to solicit the perspective of Professor John G. Ruggie, who, as the Special Representative of the UN Secretary-General led the process that resulted in the Protect, Respect and Remedy Framework and the Guiding Principles - texts which form the basis of many current debates and new initiatives in this field.

'The world is my country': that view now reflects the desire of business enterprises working across national borders, traditional structures, and mindsets to take advantage of the globalisation of exchanges. That view is also at the heart of humanitarian work, which recognises the dignity of every individual, irrespective of his or her background, opinions or beliefs. The globalisation of exchanges is a fact of life, but will only be progress if it is responsible.

Vincent Bernard Editor-in-Chief 